\title{
Preface to the Second Portuguese Edition by Moacyr Scliar 1987
}

Within any body of literature there exist some texts that, for some obscure reason, are underestimated. On a Clear April Morning falls into this category. Not so much for its literary value, which is appreciable, but which is not reflected in stylistic innovations or flights of imagination. Rather this book's value as a work of documentation is priceless. It speaks to us of an age, it speaks to us of a human experience that decisively marked Judaism and also left an indelible mark on the history of this state, Rio Grande do Sul, and of this country, Brazil. It is about the experience of emigration, an experience that, over the last two thousand years, has not been a rare occurrence in the Jewish timeline. But in this case emigration came with special circumstances.

At the end of the nineteenth century and the beginning of the twentieth, the largest segment of yishuv, the world wide Jewish community, lived within the limits of the vast Czarist Empire, in areas especially designated for Jewish settlement. The restriction was not only geographical; it was social and cultural.

Among Jews an aspiration for a better and more dignified existence never disappeared. It was achieved in two ways, through Aliyah, to the land of Israel, where the first collective settlements were formed; and by emigration to the New World. America, with its vast expanses of land, its magnificent natural wealth, and its need for labor, opened its doors to the impoverished masses of the Old World. At the entrance to the port of New York the Statue of Liberty (in whose pedestal are engraved the verses of the 
Jewish poet Emma Lazarus warmly welcoming the newly arrived) symbolized a guarantee of a life without discrimination or oppression. Millions of Jews came to the United States; a smaller number came to South America.

Here, in the Southern Cone, however, the experience was organized in a unique fashion. The Jewish Colonization Association, a Jewish philanthropic institution, acquired lands in Rio Grande do Sul and Argentina in order to promote Jewish agricultural settlements. But the enterprise did not have the expected success, for numerous reasons-the lack of resources, the inexperience of the emigrants, and the traditional political instability of Latin America, which indeed was directly felt during a bloody revolution in Rio Grande in 1923. All these factors sapped the settlers' spirits and resulted in most of them looking towards the cities.

Then began a new stage in the process, the emigrants' adaptation to the country. It required learning a new language and inserting their group into a society that was already pretty well structured. As can be imagined, it was not easy. Initially it was an arduous path, marked by hard work, by anxiety, and many times by comic or pathetic ventures.

Marcos Iolovitch speaks to us of this path. In his work, as seen only rarely, the man and the writer are one. Marcos, who I knew personally, was a gentle creature, a frail man, but elegant and endowed with a charming kindness. And he wrote exactly like that, with gentleness, with kindness and with elegance. Marcos, like many other intellectuals of his time, was socially engaged. His book of poetry, Preces Profanas (Secular Prayers), was an attack against injustice and oppression. However, Preces Profanas has none of the fierceness of political pamphleteers common among other writers.

On a Clear April Morning has a confessional dimension that can move the most indifferent reader with its innocence and sincerity. Here we have the young emigrant looking with amazed eyes at an unknown country and recording his emotions with absolute fidelity. For example, the scene in which Marcos describes the beginning of his career as a fishmonger is simply a treasure.

Why is this book important for the Brazilian public and especially for the gaucho public? Because this is a country of immigrants. Compared with Europeans all of us here are greenhorns. Long-established Brazilians have been in the country four hundred years, in Rio Grande not even that long. That is not enough time for a culture to gel. The Brazilian character is still being formed. As part of this process it is important to record the emigrant experience, but not only as historical facts, statistics, or sociological analyses. It is important to record the emigrant experience as a human 
xiv $\mid$ Preface to the Second Portuguese Edition by Moacyr Scliar1987

phenomenon, as the life of flesh and blood people. This is exactly what Marcos Iolovitch's book does. And the book is even more valuable when we consider how few books of this type we have, particularly those written by talented writers.

As for me, I have a personal debt of gratitude to this book. For me it was what is called an "inspirational" work. I reread it countless times and it never ceased to move me. I paid a small tribute to this work in my first novel A Guerra no Bom Fim, not based on the experiences of an emigrant, but rather on the experiences of a son of emigrants. I am very pleased that this tribute no longer refers to an out-of-print book. To recuperate On a Clear April Morning for the Brazilian public, the Marc Chagall Institute provides our culture with an invaluable service, and one that also supports well the goals of the Institute itself. But more than this, it pays tribute to the memory of this unforgettable figure, the Jewish-Brazilian writer Marcos Iolovitch. 